\title{
Economic Landscapes, What Are They? \\ An Application to the Brazilian Economy and to the Sugar Cane Complex
}

Joaquim J.M. Guilhoto ${ }^{1}$, Marta C. Marjotta-Maistro ${ }^{2}$, Geoffrey J.D. Hewings ${ }^{3}$

\begin{abstract}
In assessing the economic impact of a sector or group of sectors on a single or multiregional economy, input-output analysis has proven to be a popular method. . However, there has a problem in displaying all the information that can be obtained from this analytical approach. In this paper, we have tried to set new directions in the use of input-output analysis by presenting an improved way of looking at the economic landscapes. While this is not a new concept, a new meaning is explored in this paper; essentially, it will now be possible to visualize, in a simple picture, all the relations in the economy as well as being able to view how one sector is related to the other sectors/regions in the economy. These relations can be measured in terms of structural changes, production, value added, employment, imports, etc. While all the possibilities cannot be explored in this paper, the basic idea is given here and the smart reader can uncover all the various possibilities. To illustrate the power of analysis provided by the economic landscapes, an application is made to the sugar cane complex using an interregional inputoutput system for the Brazilian economy, constructed for 2 regions (Northeast and Rest of Brazil), for the years of 1985, 1992, and 1995.
\end{abstract}

\footnotetext{
${ }^{1}$ University of São Paulo, Brazil and Regional Economics Applications Laboratory (REAL) - University of Illinois, USA. E-mail: guilhoto@usp.br. This author would like to acknowledge the grant received from the Hewlett Foundation through the Center for Latin American and Caribbean Studies a the University of Illinois.

${ }^{2}$ University of São Paulo, Brazil. E-mail: mcmarjot@carpa.ciagri.usp.br.

${ }^{3}$ Regional Economics Applications Laboratory (REAL) - University of Illinois, U.S.A.
} 


\section{Introduction}

In this paper we have worked with a problem faced by many researchers, how to show, in a compact way, all the vast amount of information contained in input-output tables, and, at the same time, making it possible to understand what is going on. To do so, this paper takes some new directions through the use of economic landscapes.

The landscapes concept is not a new one, see for example Sonis, Hewings and Guo (2000), but, it is given a new meaning in this paper. While all the possibilities are not explored in this paper, the basic idea is given here and the smart reader can uncover all the various possibilities.

What are they? They are a way of viewing the economy, the axis are the sectors or the agents involved in the productive process, while the heights are the values resulted from their transaction and interaction, directly and indirectly. The heights can be values of production, value added, imports, number of people employed, differences in structural changes, etc.

An application is made considering: a) the Brazilian economy as a whole; and b) the sugar cane complex in the Northeast and in the Rest of Brazil regions. To undertake the analysis, use is made of an interregional input-output system for the Brazilian economy, constructed for 2 regions (Northeast and Rest of Brazil), for the years of 1985, 1992, and 1995.

In the next section, a brief overview of the Brazilian economy is provided as well as the role that the sugar cane complex has played in the Brazilian economy and in the 2 regions used in the paper. The third section will make a brief presentation of the methodology. In the fourth section, the landscapes are presented, while in the last section, some final comments are made.

\section{The Brazilian Economy and the Sugar Cane Complex, 1985/1995}

This section is divided into three parts; first, a brief overview of the Brazilian economy, then the general characteristics of the Brazilian macro regions, while the last part will deal with the sugar cane complex in the Brazilian economy and in the two regions being considered here, the Northeast and the Rest of Brazil regions. 


\subsection{A Brief Overview of the Brazilian Economy in the 1980's and 1990's}

In the 1980s, the Brazilian economy experienced a very low growth rate especially when compared to its long run history. In the 1980s, the national GDP grew at a yearly average rate of only $1.56 \%$ (Bonelli and Gonçalves, 1998). The 1990s can be divided into two periods; from 1990 to 1993, the economy went through a period of recession, with the GDP growing at a yearly average rate of $1.6 \%$, while industry and agriculture grew at yearly rates of $0.3 \%$ and $2.3 \%$ respectively. In the second period, from 1993 to 1997, the yearly average GDP growth rate was of 4.4\%, while industry, agriculture, and services grew, respectively, 3.8\%, 6\%, and 3.1\% (Bonelli and Gonçalves, 1998).

In 1994, investment accounted for $16.3 \%$ of Brazilian GDP; in 1995 this share grew to $19.2 \%$ (Baer, 1996 and Conjuntura Econômica, 1997). The quality of the investment also improved and at the same time there was a growth in the share of imported capital goods. This contributed to an increase in productivity; with a consequent increase in wages (5.7\% in 1993, and 6.2\% in 1995) there was also a decrease in the unemployment rates from 5.3\% in 1993 to $4.6 \%$ in 1995 (IBGE, 1997a and Conjuntura Econômica, 1997).

The strong performance of the industrial sector in the 1990 was followed by the growth in importance of the service sector, mainly due to increased subcontracting by the industrial sector after the economy was opened up, a process that started in 1990 (Bonelli and Gonçalves, 1998). While the 1980s are characterized by a closed economy, the 1990s can be said to be a decade of openness and modernization in Brazil.

Finally, we should stress the tendencies and the sectoral progress in the Brazilian economy in the last decade. The share of the industrial sector in the economy declined from $48 \%$ in 1985 to $42 \%$ in 1990 and to $34 \%$ in 1995 , while the service sector's shares grew respectively from $40 \%$, to $47 \%$ and to $54 \%$. The shares of the agricultural sector were maintained, $12 \%$ for $1985,11 \%$ for 1990 , and $12 \%$ for 1995 (Melo et al., 1998) 


\subsection{The Brazilian Macro Regions}

As show in Figure 1, Brazil is normally divided into five macro regions (IBGE 1997a,b); some summary characteristics are show in Table 1 . Note, in particular, the strong concentration of the national GDP in the Southeast region, with a share of $56.97 \%$. The Northeast on the other hand, has a much smaller share in the GDP, $13.62 \%$,

The Northeast region has serious problems of draught and in the beginning of the formation of the Brazilian State it used to be it most important region, this region has $18.28 \%$ of the Brazilian territory and $28.50 \%$ of its population.

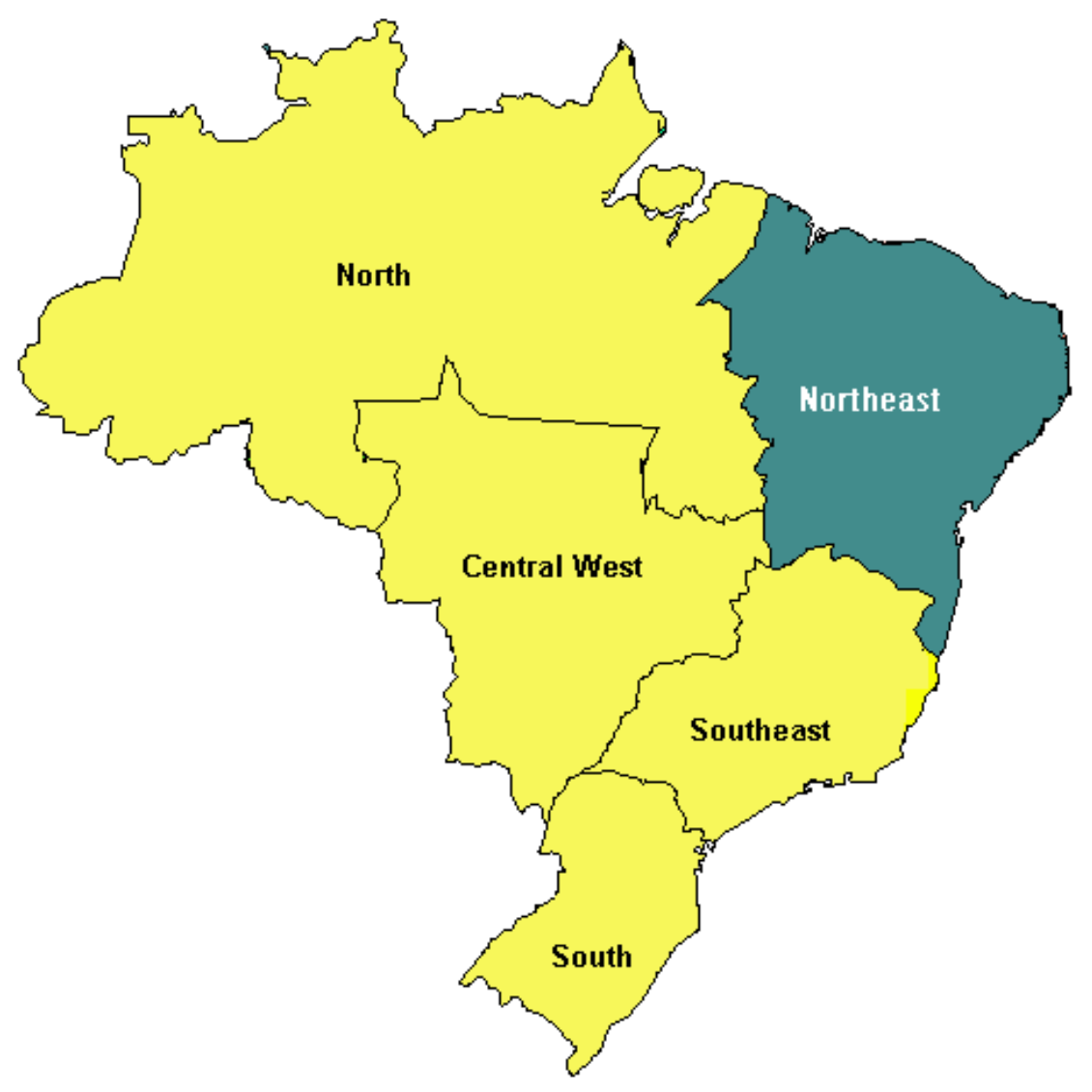

Figure 1 - Brazilian Macro Regions 
Table 1 - Main Economical and Geographical Characteristics of the Brazilian Macro Regions

\begin{tabular}{|c|c|c|c|c|c|c|}
\hline & \multicolumn{2}{|c|}{ Size } & \multicolumn{2}{|c|}{ Population (1996) } & \multirow{2}{*}{$\begin{array}{c}\text { Urban } \\
\text { Population } \\
\% \\
\end{array}$} & \multirow{2}{*}{$\begin{array}{c}\text { GDP } \\
1995 \\
\text { Share (\%) } \\
\end{array}$} \\
\hline & $\mathbf{k m}^{2}$ & Share (\%) & $\begin{array}{c}\text { Number } \\
(1,000)\end{array}$ & Share & & \\
\hline North & $3,851,560$ & 45.25 & 11,288 & 7.19 & 62.36 & 5.27 \\
\hline Northeast & $1,556,001$ & 18.28 & 44,767 & 28.50 & 65.21 & 13.62 \\
\hline Central West & $1,604,852$ & 18.85 & 10,501 & 6.69 & 84.42 & 7.25 \\
\hline Southeast & 924,266 & 10.85 & 67,001 & 42.66 & 89.29 & 56.97 \\
\hline South & 575,316 & 6.76 & 23,514 & 14.97 & 77.22 & 16.89 \\
\hline Brazil & $8,511,996$ & 100.00 & 157,070 & 100.00 & 78.36 & 100.00 \\
\hline
\end{tabular}

Source: IBGE (1997a and 1997b), Considera and Medina (1998).

\subsection{The Sugar Cane Complex}

During the last decade, the sugar cane complex has gone through a restructuring process prompted in large part by the government removing its authority to control the trade emanating from the sugar cane complex, defined as the production of sugar cane, sugar and alcohol in the economy. Until 1990, the sugar cane complex was under the strict control of the federal government, through the Sugar and Alcohol Institute, which was responsible for the control of production, price, exports, and market share of the producing Brazilian regions. In 1990, the sugar sector was the first one to be released from government control, followed by the alcohol sector in 1997. In the new context of a free market economy, the agents in the process have to learn to survive in a market free from the government rules and subsidies. Producers have to learn how to be efficient and how to gain market share by attending the consumer demands, has showed by Marjotta-Maistro (1998).

It is important to put this problem in a historic perspective, given that the Northeast region has always been a traditional producer of sugar cane, since the colonial period, and it has always been under the government control. At the same time, the other producing regions are more modern and with a more market-oriented view. This has had an impact on how the market has reacted to the opening of the sector. 
As can be seen in Table 2 and 3, since the 1989/90 the share of the Northeast region in the sugar cane production has decreased from around $27 \%$ to $17 \%$, while the share of land harvested has decreased from around $34 \%$ to $24 \%$, with almost no change in productivity. On the other hand, the share of the Rest of Brazil has increased as well as it productivity, revealing it to be a more dynamic region than the Northeast region.

If one looks at the share of the Rest of Brazil region in the production of sugar (Table 4), alcohol (Table 5), and sugar exports (Table 6), one can see that the share of this region has increase to around $90 \%$ in all of the three markets.

Understanding and interpreting these changes will provide the focus of this paper. The next section will present the theoretical background, with the following section providing the empirical relation.

Table 2 - Sugar Cane Production (1,000 Ton of Kg) and Share (\%) Northeast and Rest of Brazil Regions, 1985/86 to 1998/99

\begin{tabular}{cccccc}
\hline Year & Northeast & NE Share & Rest of Brazil & RB Share & Total \\
\hline $1985 / 86$ & 67,645 & 27.36 & 179,556 & 72.64 & 247,201 \\
$1986 / 87$ & 65,949 & 27.57 & 173,230 & 72.43 & 239,179 \\
$1987 / 88$ & 80,008 & 29.80 & 188,495 & 70.20 & 268,503 \\
$1988 / 89$ & 62,851 & 24.32 & 195,561 & 75.68 & 258,412 \\
$1989 / 90$ & 69,762 & 27.61 & 182,881 & 72.39 & 252,643 \\
$1990 / 91$ & 71,689 & 27.29 & 190,984 & 72.71 & 262,673 \\
$1991 / 92$ & 68,730 & 26.32 & 192,389 & 73.68 & 261,119 \\
$1992 / 93$ & 68,723 & 25.31 & 202,752 & 74.69 & 271,475 \\
$1993 / 94$ & 39,609 & 16.20 & 204,817 & 83.80 & 244,426 \\
$1994 / 95$ & 57,328 & 19.63 & 234,775 & 80.37 & 292,103 \\
$1995 / 96$ & 60,688 & 19.99 & 242,869 & 80.01 & 303,557 \\
$1996 / 97 *$ & 60,652 & 18.64 & 264,809 & 81.36 & 325,461 \\
$1997 / 98^{*}$ & 65,861 & 19.52 & 271,477 & 80.48 & 337,338 \\
$1998 / 99 *$ & 57,753 & 17.04 & 281,219 & 82.96 & 338,972 \\
\hline
\end{tabular}

* Includes the production of the North region

Source: Agrianual (Various Issues). 
\begin{tabular}{l|l|l|ll}
$\mathrm{R}$ & $\mathrm{E}$ & $\mathrm{A}$ & $\mathrm{L}$ & Economic Landscapes, What Are They?
\end{tabular}

Table 3 -Land of Sugar Cane Harvested (Hectares), Share (\%), and

Productivity (Ton of Kg per Hectare)

Northeast and Rest of Brazil Regions, 1985/86 to 1998/99

\begin{tabular}{cccccccc}
\hline Year & Northeast & NE Share & $\begin{array}{c}\text { NE } \\
\text { Productivity }\end{array}$ & $\begin{array}{c}\text { Rest of } \\
\text { Brazil }\end{array}$ & $\begin{array}{c}\text { RB } \\
\text { Productivity }\end{array}$ & RB Share & Total \\
\hline $1985 / 86$ & $1,330,122$ & 34.00 & 50.86 & $2,581,943$ & 66.00 & 69.54 & $3,912,065$ \\
$1986 / 87$ & $1,287,228$ & 32.57 & 51.23 & $2,664,614$ & 67.43 & 65.01 & $3,951,842$ \\
$1987 / 88$ & $1,556,454$ & 36.12 & 51.40 & $2,752,221$ & 63.88 & 68.49 & $4,308,675$ \\
$1988 / 89$ & $1,312,427$ & 31.88 & 47.89 & $2,804,948$ & 68.12 & 69.72 & $4,117,375$ \\
$1989 / 90$ & $1,378,723$ & 33.83 & 50.60 & $2,697,116$ & 66.17 & 67.81 & $4,075,839$ \\
$1990 / 91$ & $1,476,795$ & 34.44 & 48.54 & $2,810,830$ & 65.56 & 67.95 & $4,287,625$ \\
$1991 / 92$ & $1,402,388$ & 33.30 & 49.01 & $2,808,503$ & 66.70 & 68.50 & $4,210,891$ \\
$1992 / 93$ & $1,363,932$ & 32.46 & 50.39 & $2,838,572$ & 67.54 & 71.43 & $4,202,504$ \\
$1993 / 94$ & $1,022,653$ & 27.91 & 38.73 & $2,641,069$ & 72.09 & 77.55 & $3,663,722$ \\
$1994 / 95$ & $1,188,843$ & 27.35 & 48.22 & $3,157,141$ & 72.65 & 74.36 & $4,345,984$ \\
$1995 / 96$ & $1,255,966$ & 27.51 & 48.32 & $3,309,695$ & 72.49 & 73.38 & $4,565,661$ \\
$1996 / 97 *$ & $1,229,812$ & 25.43 & 49.32 & $3,606,365$ & 74.57 & 73.43 & $4,836,177$ \\
$1997 / 98 *$ & $1,276,329$ & 26.16 & 51.60 & $3,603,081$ & 73.84 & 75.35 & $4,879,410$ \\
$1998 / 99 *$ & $1,181,888$ & 23.77 & 48.87 & $3,790,125$ & 76.23 & 74.20 & $4,972,013$ \\
\hline \multirow{7}{*}{ * Includes the production of the North region } & & & & \\
Source: Agrianual (Various Issues) \\
\hline \hline
\end{tabular}

Table 4 - Sugar Production (1,000 Ton of Kg) and Share (\%)

Northeast and Rest of Brazil Regions, 1985/86 to 1999/00

\begin{tabular}{cccccc}
\hline Year & Northeast* & NE Share* & Rest of Brazil & RB Share & Total \\
\hline $1985 / 86$ & 3,199 & 40.91 & 4,620 & 59.09 & 7,819 \\
$1986 / 87$ & 3,348 & 41.04 & 4,809 & 58.96 & 8,157 \\
$1987 / 88$ & 3,158 & 39.56 & 4,825 & 60.44 & 7,983 \\
$1988 / 89$ & 2,817 & 34.91 & 5,253 & 65.09 & 8,070 \\
$1989 / 90$ & 3,096 & 42.79 & 4,140 & 57.21 & 7,236 \\
$1990 / 91$ & 2,857 & 38.77 & 4,512 & 61.23 & 7,369 \\
$1991 / 92$ & 2,831 & 32.53 & 5,873 & 67.47 & 8,704 \\
$1992 / 93$ & 3,146 & 33.40 & 6,274 & 66.60 & 9,420 \\
$1993 / 94$ & 2,318 & 24.70 & 7,067 & 75.30 & 9,385 \\
$1994 / 95$ & 3,398 & 28.48 & 8,535 & 71.52 & 11,933 \\
$1995 / 96$ & 3,085 & 24.88 & 9,315 & 75.12 & 12,400 \\
$1996 / 97$ & 3,950 & 28.21 & 10,050 & 71.79 & 14,000 \\
$1997 / 98$ & 4,435 & 27.72 & 11,565 & 72.28 & 16,000 \\
$1998 / 99$ & 3,099 & 16.93 & 15,201 & 83.07 & 18,300 \\
$1999 / 00$ & 2,115 & 11.12 & 16,899 & 88.88 & 19,014 \\
\hline
\end{tabular}

* Includes the production of the North region

Source: Associação das Indústrias de Açúcar e Álcool do Estado de São Paulo, USDA, União da Agroindústria Canavieira do Estado de São Paulo. 
\begin{tabular}{l|l|l|ll}
$\mathrm{R}$ & $\mathrm{E}$ & $\mathrm{A}$ & $\mathrm{L}$ & Economic Landscapes, What Are They?
\end{tabular}

Table 5 - Alcohol Production (Millions of $\mathrm{m}^{3}$ ) and Share (\%)

Northeast and Rest of Brazil Regions, 1985/86 to 1999/00

\begin{tabular}{cccccc}
\hline Year & Northeast* & NE Share* & Rest of Brazil & RB Share & Total \\
\hline $1985 / 86$ & 2,021 & 17.10 & 9,799 & 82.90 & 11,820 \\
$1986 / 87$ & 2,215 & 21.06 & 8,301 & 78.94 & 10,516 \\
$1987 / 88$ & 1,787 & 15.60 & 9,667 & 84.40 & 11,454 \\
$1988 / 89$ & 1,754 & 14.97 & 9,959 & 85.03 & 11,713 \\
$1989 / 90$ & 1,980 & 16.67 & 9,901 & 83.33 & 11,881 \\
$1990 / 91$ & 1,807 & 15.34 & 9,976 & 84.66 & 11,783 \\
$1991 / 92$ & 1,776 & 14.01 & 10,905 & 85.99 & 12,681 \\
$1992 / 93$ & 1,672 & 14.25 & 10,064 & 85.75 & 11,736 \\
$1993 / 94$ & 909 & 8.06 & 10,369 & 91.94 & 11,278 \\
$1994 / 95$ & 1,579 & 12.41 & 11,147 & 87.59 & 12,726 \\
$1995 / 96$ & 1,833 & 14.45 & 10,856 & 85.55 & 12,689 \\
$1996 / 97$ & 1,900 & 13.54 & 12,130 & 86.46 & 14,030 \\
$1997 / 98$ & 1,700 & 11.33 & 13,300 & 88.67 & 15,000 \\
$1998 / 99$ & 1,200 & 8.96 & 12,200 & 91.04 & 13,400 \\
$1999 / 00$ & 1,146 & 8.97 & 11,624 & 91.03 & 12,770 \\
\hline
\end{tabular}

* Includes the production of the North region

Source: Associação das Indústrias de Açúcar e Álcool do Estado de São Paulo, USDA, União da Agroindústria Canavieira do Estado de São Paulo.

Table 6 - Sugar Exports (Ton of Kg) and Share (\%) Northeast and Rest of Brazil Regions, 1985/86 to 1999/00

\begin{tabular}{cccccc}
\hline Year & Northeast* & NE Share* & Rest of Brazil & RB Share & Total \\
\hline $1988 / 89$ & $1,363,921$ & 88.22 & 182,111 & 11.78 & $1,546,032$ \\
$1989 / 90$ & $1,250,524$ & 81.39 & 285,844 & 18.61 & $1,536,368$ \\
$1990 / 91$ & $1,197,013$ & 85.18 & 208,269 & 14.82 & $1,405,282$ \\
$1991 / 92$ & $1,302,528$ & 76.42 & 401,919 & 23.58 & $1,704,447$ \\
$1992 / 93$ & $1,312,807$ & 61.21 & 831,837 & 38.79 & $2,144,644$ \\
$1993 / 94$ & 862,535 & 33.76 & $1,692,454$ & 66.24 & $2,554,989$ \\
$1994 / 95$ & $1,815,924$ & 43.95 & $2,315,457$ & 56.05 & $4,131,381$ \\
$1995 / 96$ & $1,639,355$ & 36.29 & $2,877,492$ & 63.71 & $4,516,847$ \\
$1996 / 97$ & $1,484,044$ & 30.90 & $3,319,430$ & 69.10 & $4,803,474$ \\
$1997 / 98$ & $2,060,711$ & 33.65 & $4,062,442$ & 66.35 & $6,123,153$ \\
$1998 / 99$ & 819,828 & 12.76 & $5,603,272$ & 87.24 & $6,423,100$ \\
\hline
\end{tabular}

* Includes the exports of the North region

Source: Moraes (2000) 


\section{Theoretical Background}

Define a standard Leontief system:

$$
X=A X+Y
$$

where $X$ is a vector $(n \times 1)$ of total production by sector; $Y\left(\begin{array}{ll}n & \times 1\end{array}\right)$ is the final demand; and $A$ is a $(n x$ $n$ ) matrix of technical coefficients.

The usual solution is:

$$
X=B Y
$$

and

$$
B=(I-A)^{-1}
$$

where $B(n \times n)$ is the Leontief inverse matrix.

To construct an economic landscape, in production values, to show how the economic system will work directly and indirectly to produce one unit of the $j^{\text {th }}$ sector for the final demand, the $A$ matrix of direct coefficients is post multiplied by the diagonal of the $\mathrm{j}^{\text {th }}$ column of matrix $B\left(\hat{B}_{\bullet}{ }_{j}\right)$, i.e.:

$$
L_{j}=A\left(\hat{B}_{\bullet j}\right)
$$

where $L_{j}$ is the economic landscape for sector $j$.

To estimate the economic landscape for a given sector in the economy, in terms of value added, employment, imports, etc. this can be done by first estimating the coefficient of the value added, for example, as:

$$
w_{k}=\frac{V A_{k}}{X_{k}}
$$

where $w_{k}$ is the coefficient of the value added for sector $k, V A_{k}$ is the value added of sector $k$, and $X_{k}$ is the production level of sector $k$.

After which, it is obtained the value added generated, directly and indirectly, in each sector by the sale of one unit of sector $j$ to the final demand $\left(v_{k j}\right)$, i.e.,

$$
v_{k j}=w_{k} b_{k j}
$$


where $b_{k j}$ is an element of the matrix $B$ defined above.

To obtain the value added matrix of sector $j$ that will be used to construct the value added economic landscape for this sector $\left(L_{j}^{w}\right)$, one first get the share of each direct coefficient in a given row $\left(e_{i j}\right)$, then the resulting matrix is post multiplied by the diagonal matrix of vector $v$. In that way:

$$
\begin{aligned}
e_{i j} & =\frac{a_{i j}}{\sum_{i=1}^{n} a_{i j}} \\
L_{j}^{w} & =E\left(\hat{V}_{j}\right)
\end{aligned}
$$

The next section will present the economic landscapes for the two Brazilian regions considered in this paper with a particular focus on the sugar cane complex.

\section{Economic Landscapes and Structural Changes}

In this section, an analysis will be made of the structural changes that took place in the Brazilian economy from 1985 to 1992 and from 1992 to 1995 at the level of 2 Brazilian regions, Northeast and Rest of Brazil. After this macro perspective, attention will be directed to how the sugar cane complex changed in the same time period, for the two regions, and how these changes can the related to the changes that occurred in the economy as a whole.

\subsection{The Brazilian Economy}

The information for the analysis of the structural changes in the Brazilian economy are shown in Tables 7 and 8 and displayed in economic landscapes presented in Figures 2 to 5. The economic landscapes show four blocks: in the upper right corner are the transactions within the Northeast while in the upper left corner one has the sales from the Northeast region to the Rest of Brazil. In the bottom part, one has first, the sales from the Rest of Brazil to the Northeast while the final part reveals the transactions inside the Rest of Brazil region. 
When comparing the differences among the regions, for 1995, notice that the total height of the Rest of Brazil region (29.96) is larger than the one for the Northeast region (18.65) implying that the Rest of Brazil region has a more linked productive process which is an indication of a higher level of development, confirmed by the data presented into section 2. Concerning the interregional transactions, one can see that there is a greater dependence of the Northeast region on the Rest of Brazil (total height value of 6.85) than the Rest of Brazil on the Northeast region (total height value of 1.36).

\begin{tabular}{|c|c|c|c|}
\hline \multicolumn{4}{|c|}{$\begin{array}{l}\text { Table } 7 \text { - Sum of the Landscapes Heights from the Leontief Inverse } \\
\text { Northeast and Rest of Brazil Regions: } 1985,1992 \text {, and } 1995\end{array}$} \\
\hline Quadrant & 1985 & 1992 & 1995 \\
\hline Northeast to Northeast & 20.78 & 20.71 & 18.65 \\
\hline Northeast to Rest of Brazil & 1.64 & 1.62 & 1.36 \\
\hline Rest of Brazil to Northeast & 10.33 & 9.97 & 6.85 \\
\hline Rest of Brazil to Rest of Brazil & 34.16 & 33.92 & 29.96 \\
\hline Total & 66.91 & 66.22 & 56.82 \\
\hline
\end{tabular}

Table 8 - Changes and Growth Rates (\%) of the Sum of the Landscapes Heights from the Leontief Inverse - Northeast and Rest of Brazil Regions: 1985, 1992, and 1995

\begin{tabular}{ccccccc}
\hline \multirow{2}{*}{ Quadrant } & \multicolumn{3}{c}{ Changes } & \multicolumn{3}{c}{ Growth Rates (\%) } \\
& $1992-1985$ & $1995-1992$ & $1995-1985$ & $1992-1985$ & $1995-1992$ & $1995-1985$ \\
\hline Northeast to Northeast & -0.07 & -2.06 & -2.12 & -0.33 & -9.93 & -10.23 \\
Northeast to Rest of Brazil & -0.02 & -0.26 & -0.28 & -1.26 & -16.00 & -17.06 \\
Rest of Brazil to Northeast & -0.36 & -3.12 & -3.48 & -3.45 & -31.33 & -33.70 \\
Rest of Brazil to Rest of Brazil & -0.24 & -3.96 & -4.20 & -0.71 & -11.68 & -12.31 \\
$\quad$ Total & -0.69 & -9.40 & -10.09 & -1.03 & -14.20 & -15.08 \\
\hline \multirow{2}{*}{ Source: Estimated by the authors } & \multicolumn{5}{c}{} \\
\hline \hline
\end{tabular}


The economic landscapes for 1985 and 1995 and the difference between them show that there was a decrease in the overall height of the economy, given that the amount of production in the productive process that is necessary to generate of unit of final demand for each one of the 70 sectors in the economy (35 in each region) has decreased from 66.91 to 56.82 . However, this change has not been equal all over the economy and through time.

From 1985 to 1992, there were practically no changes in the way that the economy behaved as can be seen in Figure 5 and to the fact that the total value of the heights decreased only from 66.91 to 66.21. The big change occurred from 1992 to 1995 when this value decreased by $14.20 \%$ to 56.82 . This can be explained in part by the openness of the economy, started in the 1990's, that probably has increased the dependence on imported goods and as a consequence probably decreased the value of the transactions inside the productive process of the Brazilian economy. This may be and indication of "hollowing out" (see Hewings et al 1998), whereby an economy becomes more dependent on external markets for inputs and sales. Clearly, the opening up of the economy contributed to this phenomena.

Also this change was not homogenous through out the two regions in the system, while the overall decrease of the heights from 1985 to 1995 was of $15.08 \%$, the highest decreases are found in the transactions among the regions with the heights of the sales from the Northeast to the Rest of Brazil decreasing by $17.06 \%$, while those from the Rest of Brazil to the Northeast region decreased by $33.70 \%$. Once more this could be the result of the openness process, suggesting that the Northeast region might have increased its transactions with markets external to the country in place of transactions with the Rest of Brazil.

Now attention will be directed to the analysis of the sugar cane complex in the Brazilian economy and on its regions. 


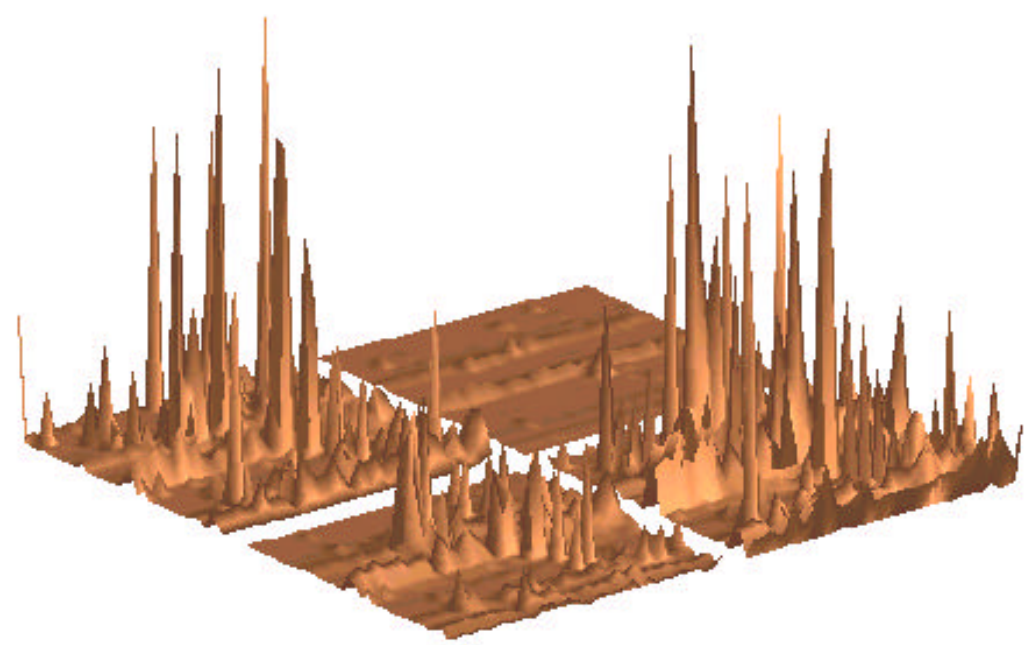

Total

Leontief Inverse 1985

Figure 2 - Economic Landscape of the Leontief Inverse Northeast and Rest of Brazil Regions: 1985

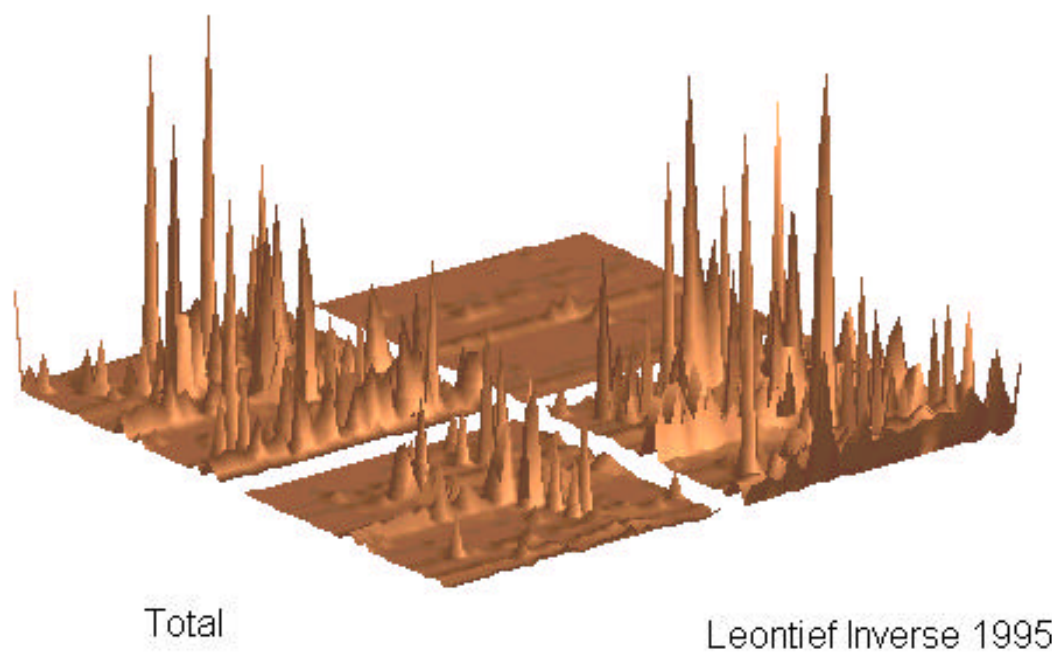

Figure 3 - Economic Landscape of the Leontief Inverse Northeast and Rest of Brazil Regions: 1995 


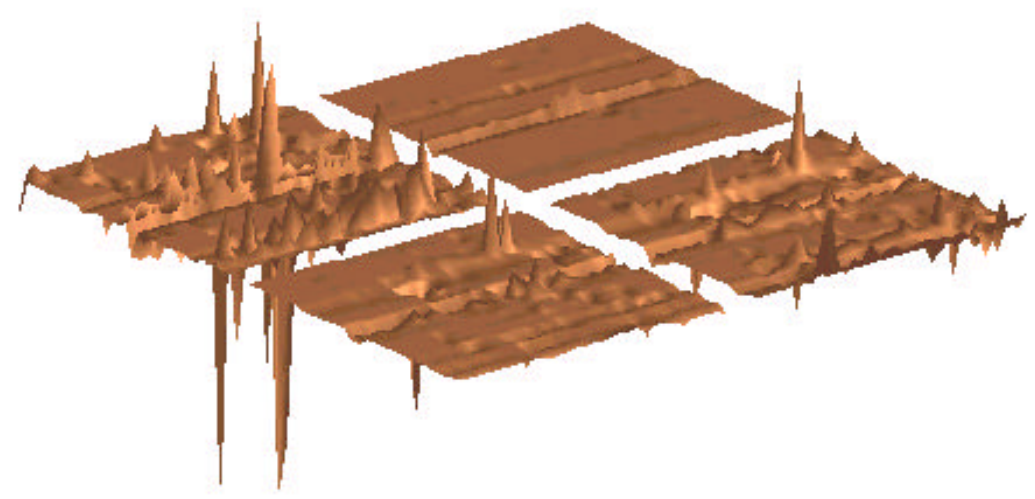

Total

LI (1995 - 1985)

Figure 4 - Economic Landscape of the Changes in the Leontief Inverse Northeast and Rest of Brazil Regions: 1995 Less 1985

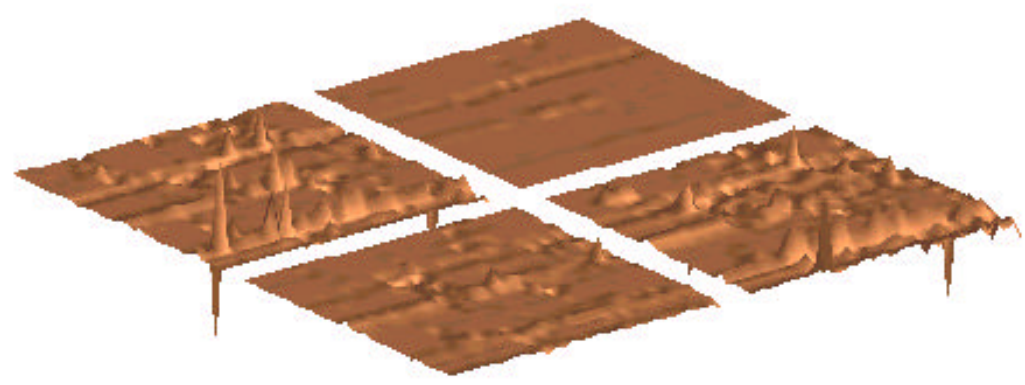

Total

LI (1992 - 1985)

Figure 5 - Economic Landscape of the Changes in the Leontief Inverse Northeast and Rest of Brazil Regions: 1992 Less 1985 


\subsection{The Sugar Cane Complex}

Information for the sugar cane complex, consisting of the sugar cane, alcohol, and sugar sectors is revealed into Tables 9 to 12, in Figures 6 to 11 for the Northeast, and in Tables 13 to 16 and Figures 12 to 17 for the Rest of Brazil. For the Northeast (Tables 9 to 11) it is possible to see that the biggest changes in the way that the sugar cane complex behaved from 1985 to 1995 occurred in the 1992 to 1995 period, following the overall trend observed for the economy as a whole. The same happened for the Rest of Brazil (Tables 13 to 16). However, if one looks at Tables 2 to 6 above, it is clear that the changes occurred in the sugar cane complex of the Northeast were negative, given that the complex has continuously been loosing market share in the economy, while the sugar cane complex in the Rest of Brazil region gained market share. This can be explained in part by the fact that the overall heights of the Sugar Cane complex in the Rest of Brazil are higher than the ones at the Northeast region, meaning a more modern and integrated complex with the rest of the economy. In addition, the sugar cane complex in the Northeast decreased its transactions with the Rest of Brazil region, isolating itself from the modernization process occurred in the Rest of Brazil.

Looking at Figures 6 to 11 for the Northeast, it is clear that the one sector more dependent than others on inputs from the Rest of Brazil is the sugar sane sector, probably due to the necessity that this sector has of modern inputs used in the productive process, while the production of alcohol and sugar depend mainly on the inputs of the sugar cane sector, that are available locally. Also, the overall height of the alcohol and sugar sectors are larger than the ones of the sugar cane sector meaning that these sectors have a larger multiplier effect in the economy than the one revealed by the sugar cane sector alone.

It is also possible to see that the economic landscapes for the relation of inputs inside the productive process is different from the ones generated when the value added is used. This is clear when comparing Figures 6, 8, and 10 with, respectively, Figures 7, 9, 11. The share of the value added generated in each region is given in Table 11, while Table 12 shows the dependence of the total value added on the transactions that occur in the productive process. Table 12 can be interpreted as a combination of the information provided in Tables 10 and 11. From Figures 9 and 11, it is clear the dependence of the value added generated on the alcohol and sugar sectors on the sugar cane sector, 
what was already expected, giving that the sugar cane sector is the main supplier of inputs to both of these sectors.

Table 9 - Sum of the Landscapes Heights for Inputs and Value Added:

Sugar Cane, Alcohol, and Sugar Sectors - Northeast: 1985, 1992, and 1995

\begin{tabular}{ccccc}
\hline Landscape & Year & Sugar Cane & Alcohol & Sugar \\
\hline Inputs & 1985 & 0.33 & 0.95 & 1.00 \\
Inputs & 1992 & 0.37 & 0.95 & 1.01 \\
Inputs & 1995 & 0.22 & 0.77 & 0.87 \\
& & & & \\
Value Added & 1985 & 0.97 & 0.97 & 0.97 \\
Value Added & 1992 & 0.94 & 0.95 & 0.95 \\
Value Added & 1995 & 0.95 & 0.98 & 0.98 \\
\hline
\end{tabular}

Source: Estimated by the authors

Table 10 - Share (\%) of the Sum of the Landscapes Heights for Inputs in each Quadrant: Sugar Cane, Alcohol, and Sugar Sectors - Northeast: 1985, 1992, 1995

\begin{tabular}{ccccc}
\hline Year & Quadrant & Sugar Cane & Alcohol & Sugar \\
\hline 1985 & Northeast to Northeast & 57.20 & 86.01 & 85.74 \\
1985 & Northeast to Rest of Brazil & 0.70 & 0.23 & 0.25 \\
1985 & Rest of Brazil to Northeast & 22.92 & 7.18 & 7.32 \\
1985 & Rest of Brazil to Rest of Brazil & 19.19 & 6.58 & 6.69 \\
& & & 85.35 \\
1992 & Northeast to Northeast & 57.22 & 83.88 & 0.23 \\
1992 & Northeast to Rest of Brazil & 0.65 & 0.25 & 7.62 \\
1992 & Rest of Brazil to Northeast & 23.06 & 8.43 & 6.80 \\
1992 & Rest of Brazil to Rest of Brazil & 19.07 & 7.44 & 94.00 \\
1995 & & & 94.29 & 0.10 \\
1995 & Northeast to Northeast & 71.50 & 0.10 & 3.32 \\
1995 & Northeast to Rest of Brazil & 0.48 & 3.19 & 2.58 \\
1995 & Rest of Brazil to Northeast & 16.11 & 2.42 & \\
\hline
\end{tabular}


Table 11 - Share (\%) of the Value Added in each Region:

Sugar Cane, Alcohol, and Sugar Sectors - Northeast: 1985, 1992, 1995

\begin{tabular}{ccccc}
\hline Year & Region & Sugar Cane & Alcohol & Sugar \\
\hline 1985 & Northeast & 94.49 & 94.96 & 94.67 \\
1985 & Rest of Brazil & 5.51 & 5.04 & 5.33 \\
& & & & \\
1992 & Northeast & 92.95 & 93.45 & 93.75 \\
1992 & Rest of Brazil & 7.05 & 6.55 & 6.25 \\
& & & & \\
1995 & Northeast & 97.09 & 98.04 & 97.70 \\
1995 & Rest of Brazil & 2.91 & 1.96 & 2.30 \\
\hline
\end{tabular}

Source: Estimated by the authors

Table 12 - Share (\%) of the Sum of the Landscapes Heights for Value Added in each Quadrant: Sugar Cane, Alcohol, and Sugar Sectors Northeast: 1985, 1992, 1995

\begin{tabular}{ccccc}
\hline Year & Quadrant & Sugar Cane & Alcohol & Sugar \\
\hline 1985 & Northeast to Northeast & 64.09 & 76.98 & 76.56 \\
1985 & Northeast to Rest of Brazil & 0.15 & 0.14 & 0.15 \\
1985 & Rest of Brazil to Northeast & 30.40 & 17.98 & 18.11 \\
1985 & Rest of Brazil to Rest of Brazil & 5.36 & 4.90 & 5.18 \\
& & & 77.17 & 76.86 \\
1992 & Northeast to Northeast & 63.77 & 0.20 & 0.19 \\
1992 & Northeast to Rest of Brazil & 0.21 & 16.28 & 16.90 \\
1992 & Rest of Brazil to Northeast & 29.18 & 6.36 & 6.05 \\
1992 & Rest of Brazil to Rest of Brazil & 6.83 & & \\
& & & 87.70 & 86.30 \\
1995 & Northeast to Northeast & 78.26 & 0.07 & 0.08 \\
1995 & Northeast to Rest of Brazil & 0.11 & 10.33 & 11.40 \\
1995 & Rest of Brazil to Northeast & 18.83 & 1.89 & 2.22 \\
1995 & Rest of Brazil to Rest of Brazil & 2.81 & & \\
\hline
\end{tabular}

Source: Estimated by the authors 


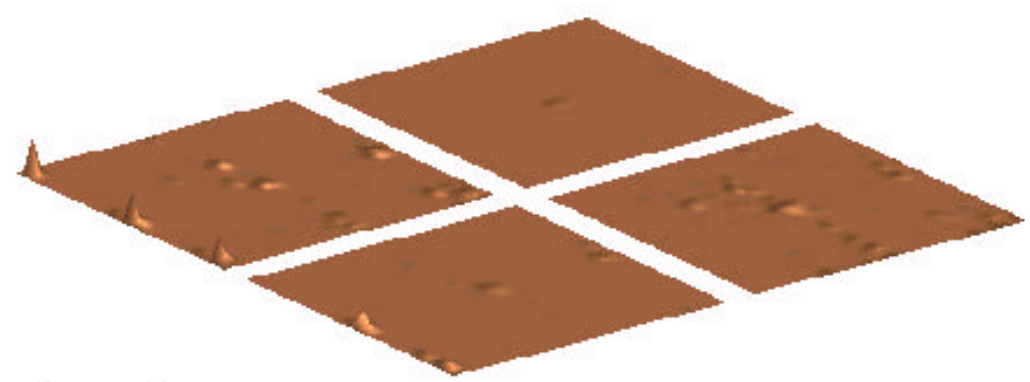

Sugar Cane

Inputs - NE 1995

Figure 6 - Economic Landscape for Inputs of the Sugar Cane Sector in the Northeast Region: 1995

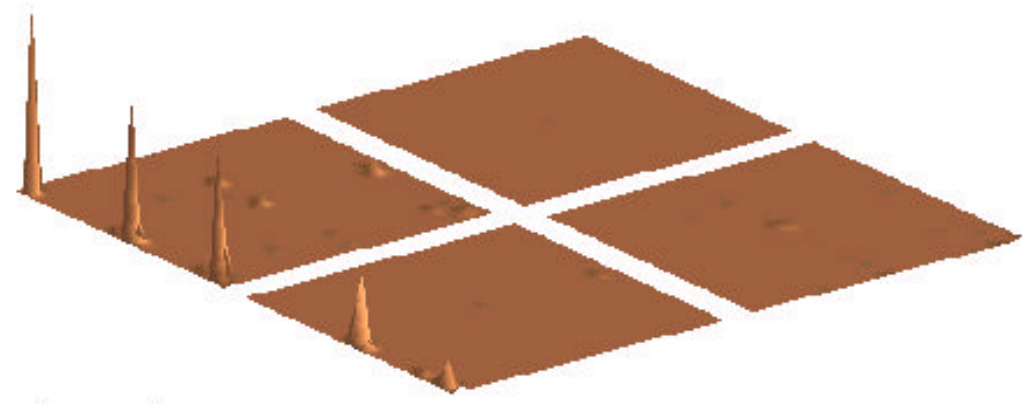

Sugar Cane

VA - NE 1995

Figure 7 - Economic Landscape for Value Added of the Sugar Cane Sector In the Northeast Region: 1995 


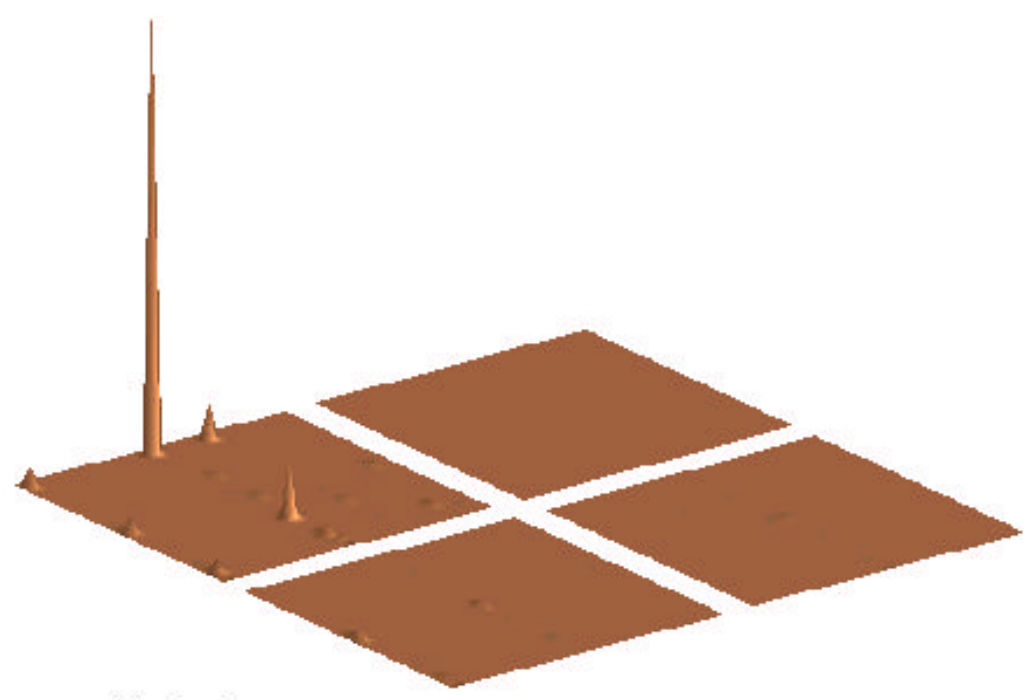

A.cohol

Inputs - NE 1995

Figure 8 - Economic Landscape for Inputs of the Alcohol Sector in the Northeast Region: 1995

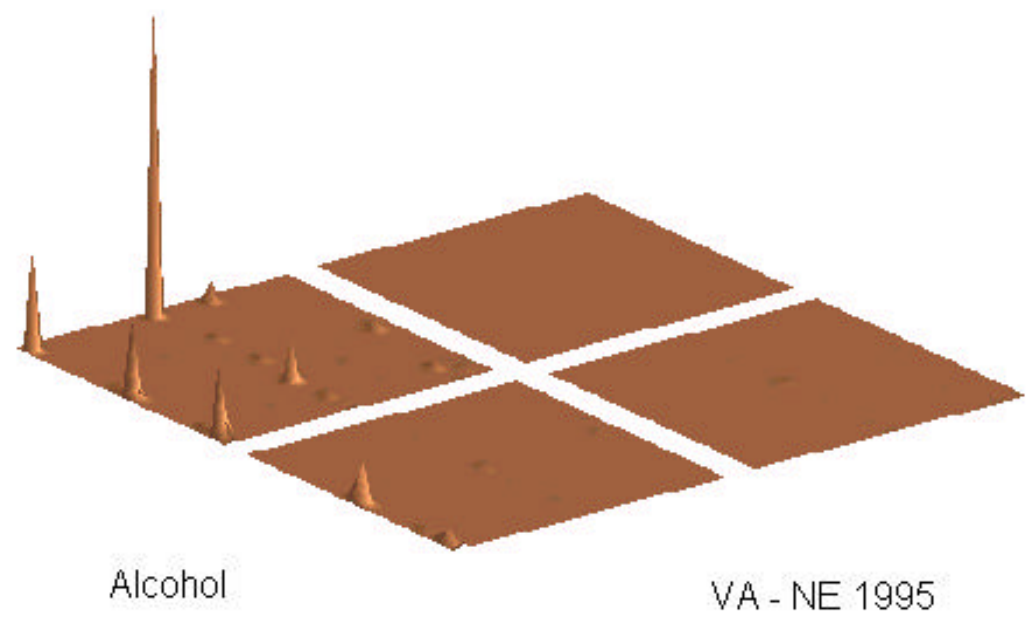

Figure 9 - Economic Landscape for Value Added of the Alcohol Sector in the Northeast Region: 1995 


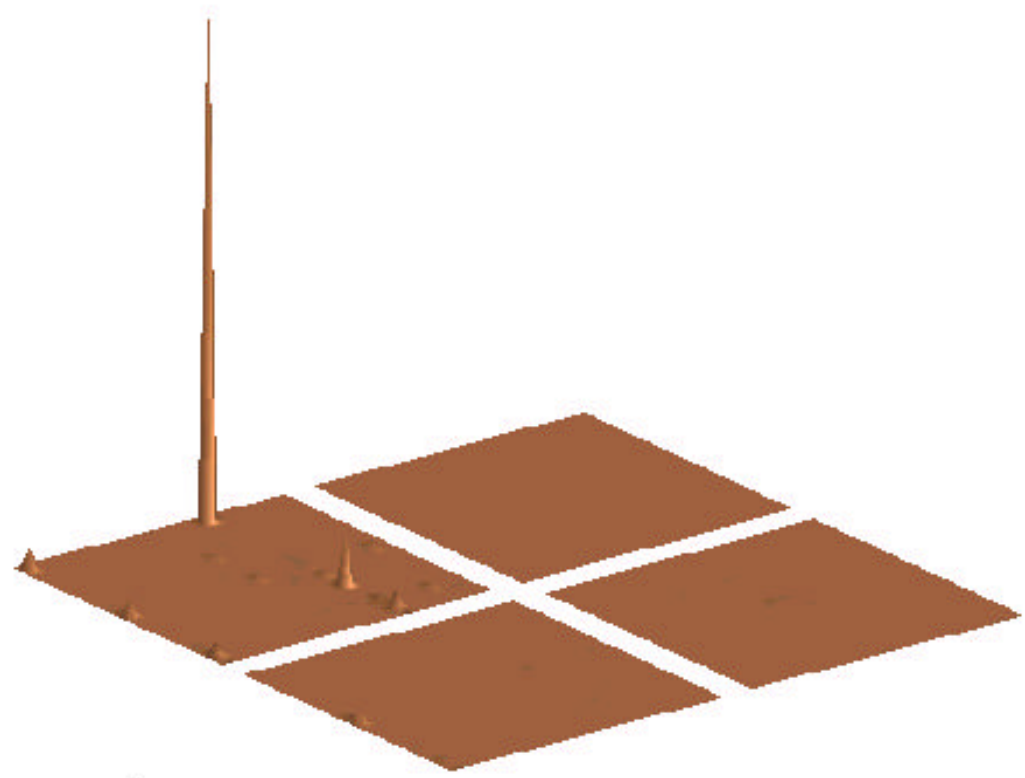

Sugar

Inputs - NE 1995

Figure 10 - Economic Landscape for Inputs of the Sugar Sector in the Northeast Region: 1995

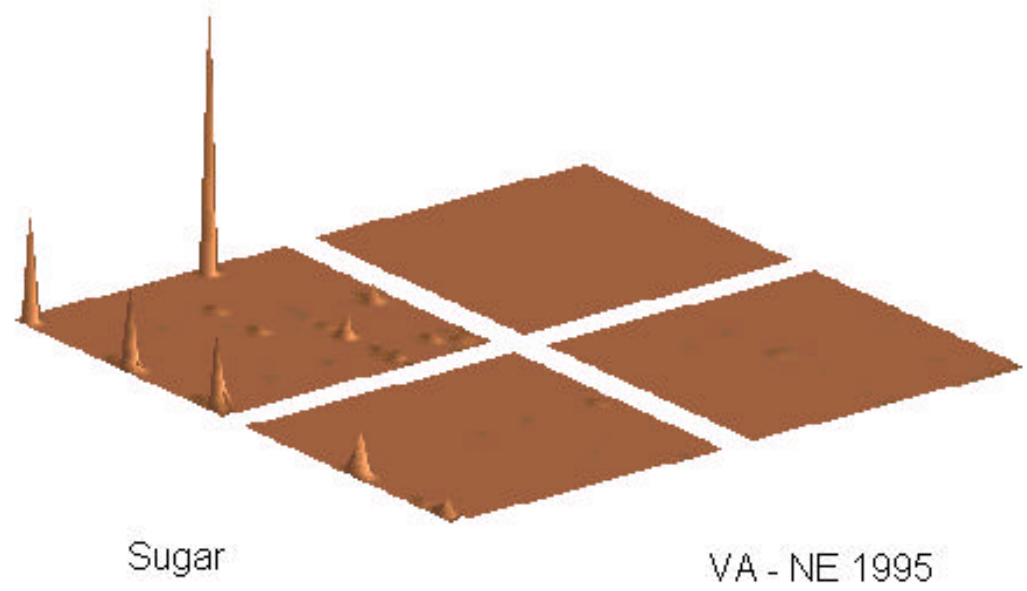

Figure 11 - Economic Landscape for Value Added of the Sugar Sector in the Northeast Region: 1995 
Table 13 - Sum of the Landscapes Heights for Inputs and Value Added: Sugar Cane, Alcohol, and Sugar Sectors - Rest of Brazil: 1985, 1992, and 1995

\begin{tabular}{ccccc}
\hline Landscape & Year & Sugar Cane & Alcohol & Sugar \\
\hline Inputs & 1985 & 0.46 & 1.15 & 1.62 \\
Inputs & 1992 & 0.51 & 1.11 & 1.58 \\
Inputs & 1995 & 0.38 & 0.97 & 1.50 \\
& & & & \\
Value Added & 1985 & 0.93 & 0.95 & 0.91 \\
Value Added & 1992 & 0.91 & 0.92 & 0.88 \\
Value Added & 1995 & 0.92 & 0.93 & 0.87 \\
\hline
\end{tabular}

Source: Estimated by the authors

Table 14 - Share (\%) of the Sum of the Landscapes Heights for Inputs in each Quadrant: Sugar Cane, Alcohol, and Sugar Sector Rest of Brazil: 1985, 1992, 1995

\begin{tabular}{ccccc}
\hline Year & Quadrant & Sugar Cane & Alcohol & Sugar \\
\hline 1985 & Northeast to Northeast & 3.54 & 1.19 & 1.48 \\
1985 & Northeast to Rest of Brazil & 3.88 & 1.43 & 1.76 \\
1985 & Rest of Brazil to Northeast & 0.75 & 0.25 & 0.31 \\
1985 & Rest of Brazil to Rest of Brazil & 91.83 & 97.12 & 96.46 \\
& & & & \\
1992 & Northeast to Northeast & 3.39 & 1.64 & 1.47 \\
1992 & Northeast to Rest of Brazil & 3.67 & 1.78 & 1.70 \\
1992 & Rest of Brazil to Northeast & 0.78 & 0.38 & 0.33 \\
1992 & Rest of Brazil to Rest of Brazil & 92.15 & 96.20 & 96.50 \\
& & & & \\
1995 & Northeast to Northeast & 1.90 & 0.94 & 1.34 \\
1995 & Northeast to Rest of Brazil & 3.55 & 1.59 & 2.16 \\
1995 & Rest of Brazil to Northeast & 0.27 & 0.13 & 0.18 \\
1995 & Rest of Brazil to Rest of Brazil & 94.27 & 97.33 & 96.32 \\
\hline
\end{tabular}

Source: Estimated by the authors 
Table 15 - Share (\%) of the Value Added in each Region: Sugar Cane, Alcohol, and Sugar Sectors - Rest of Brazil: 1985, 1992, 1995

\begin{tabular}{ccccc}
\hline Year & Region & Sugar Cane & Alcohol & Sugar \\
\hline 1985 & Northeast & 1.43 & 1.34 & 2.43 \\
1985 & Rest of Brazil & 98.57 & 98.66 & 97.57 \\
& & & & \\
1992 & Northeast & 1.51 & 1.58 & 2.32 \\
1992 & Rest of Brazil & 98.49 & 98.42 & 97.68 \\
& & & & \\
1995 & Northeast & 1.28 & 1.41 & 3.17 \\
1995 & Rest of Brazil & 98.72 & 98.59 & 96.83 \\
\hline
\end{tabular}

Source: Estimated by the authors

Table 16 - Share (\%) of the Sum of the Landscapes Heights for Value Added in each Quadrant: Sugar Cane, Alcohol, and Sugar Sectors Rest of Brazil: 1985, 1992, 1995

\begin{tabular}{ccccc}
\hline Year & Quadrant & Sugar Cane & Alcohol & Sugar \\
\hline 1985 & Northeast to Northeast & 1.22 & 1.13 & 2.03 \\
1985 & Northeast to Rest of Brazil & 4.22 & 2.52 & 2.83 \\
1985 & Rest of Brazil to Northeast & 0.21 & 0.22 & 0.41 \\
1985 & Rest of Brazil to Rest of Brazil & 94.35 & 96.13 & 94.74 \\
& & & & \\
1992 & Northeast to Northeast & 1.27 & 1.31 & 1.91 \\
1992 & Northeast to Rest of Brazil & 3.94 & 2.45 & 2.64 \\
1992 & Rest of Brazil to Northeast & 0.24 & 0.27 & 0.4 \\
1992 & Rest of Brazil to Rest of Brazil & 94.55 & 95.97 & 95.04 \\
& & & & \\
1995 & Northeast to Northeast & 1.16 & 1.26 & 2.84 \\
1995 & Northeast to Rest of Brazil & 3.52 & 2.16 & 2.72 \\
1995 & Rest of Brazil to Northeast & 0.12 & 0.14 & 0.33 \\
1995 & Rest of Brazil to Rest of Brazil & 95.20 & 96.43 & 94.11 \\
\hline
\end{tabular}

Source: Estimated by the authors 


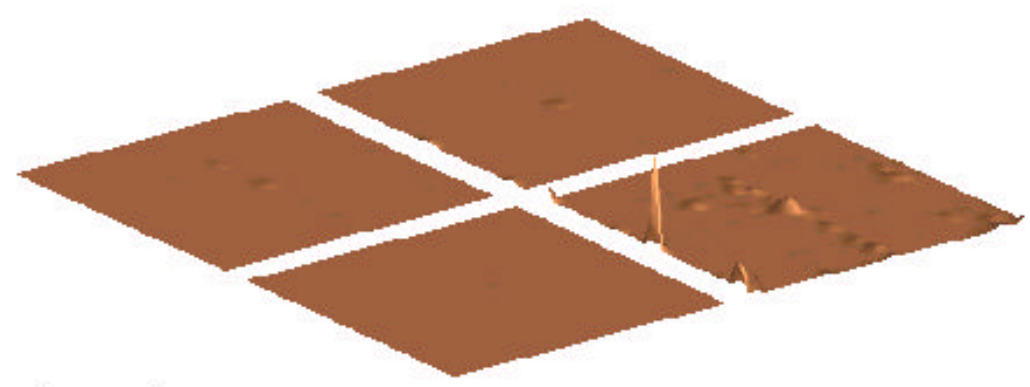

Sugar Cane

Inputs - RB 1995

Figure 12 - Economic Landscape for Inputs of the Sugar Cane Sector in the Rest of Brazil Region: 1995

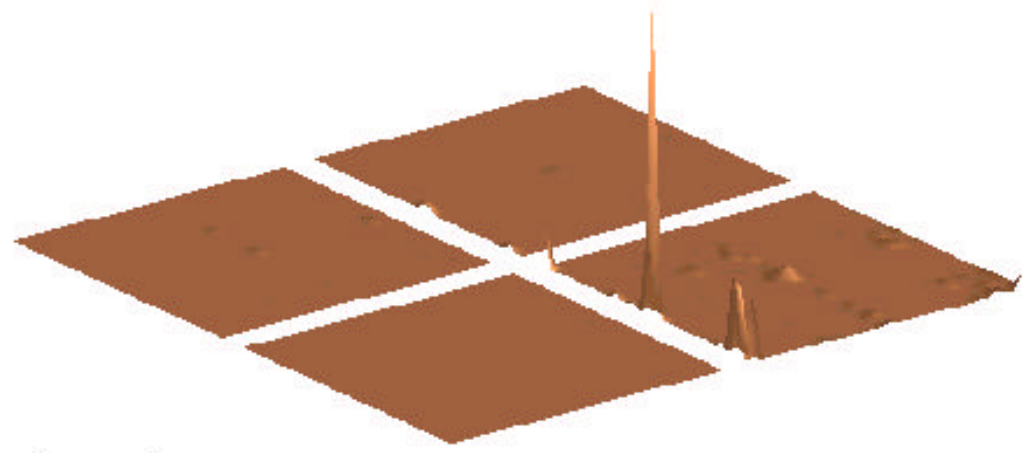

Sugar Cane

VA - RB 1995

Figure 13 - Economic Landscape for Value Added of the Sugar Cane Sector in the Rest of Brazil Region: 1995 


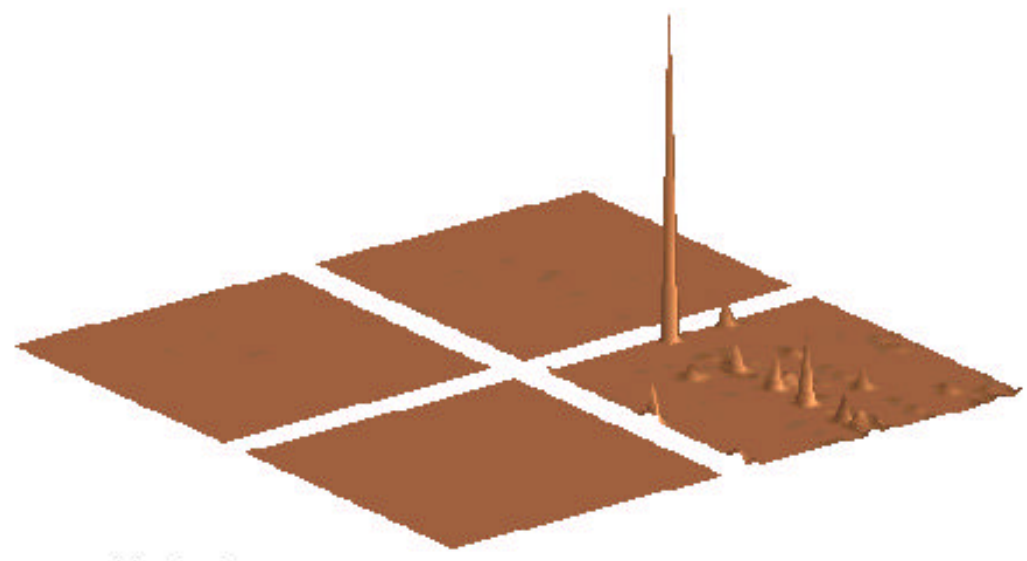

Alcohol

Inputs - RB 1995

Figure 14 - Economic Landscape for Inputs of the Alcohol Sector in the Rest of Brazil Region: 1995

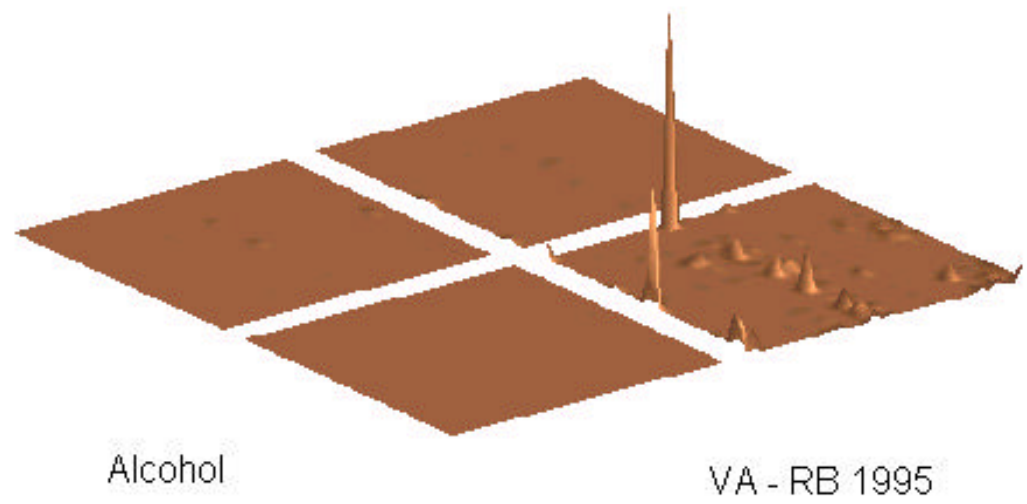

Figure 15 - Economic Landscape for Value Added of the Alcohol Sector in the Rest of Brazil Region: 1995 


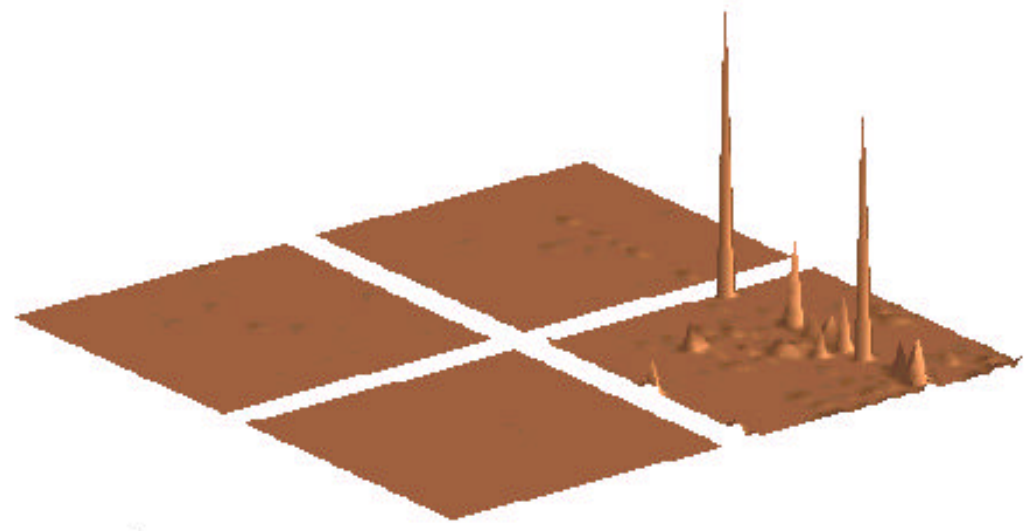

Sugar

Inputs - RB 1995

Figure 16 - Economic Landscape for Inputs of the Sugar Sector in the Rest of Brazil Region: 1995

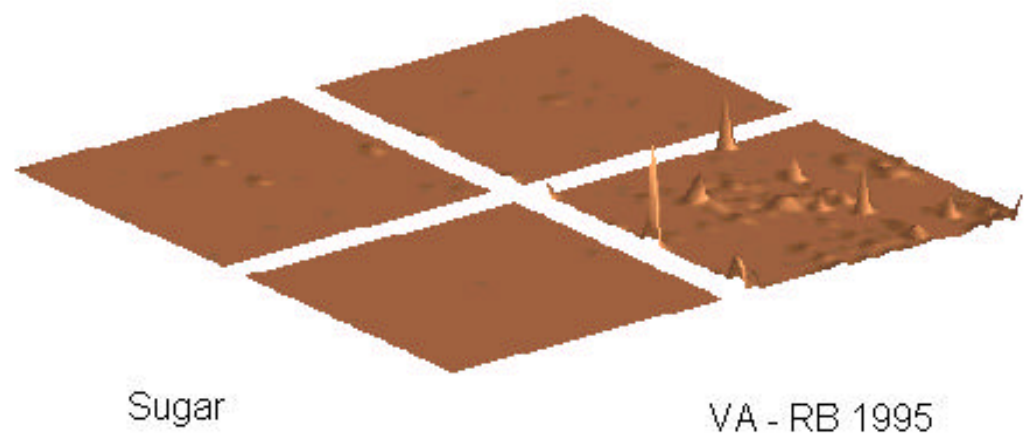

Figure 17 - Economic Landscape for Value Added of the Sugar Sector in the Rest of Brazil Region: 1995 
For the Rest of Brazil, from Figures 11 to 17 , it is possible to see that there are more links among the sectors than in the Northeast region, which is an indication of more modernity of the sectors, this is also confirmed by the fact that, as observed above, for the inputs used in the productive process (Figures 12, 14, and 16) the total sum of the heights are bigger in the Rest of Brazil region (Tables 9 and 13). Considering the dependence of the sectors between the regions (Tables 10, 12, 14, and 16) the sectors in the Northeast region are more dependent on the sectors of the Rest of Brazil than vice-versa.

As a general conclusion, it is possible to say that the sugar cane complex in the Rest of Brazil economy has show to be a more modern and dynamic complex when compared to the one in the Northeast region, and as a result of that has gained share in the market, mainly after 1992 that was when the openness process started in the economy and the government stepped out from the sector.

\section{Final Comments}

This paper presented a new concept of analysis through the use of economic landscapes. This concept can be used to better understand, in a visual way, how the structural changes take place in the economy as a whole, and how the transactions vary in magnitude and direction among the regions. Further, The economic landscapes can also be used to determine the relations of a given sector, with the other sectors and regions.

The use of economic landscapes is illustrated in this paper through an application to the Brazilian economy and to its Sugar Cane complex, using an interregional input-output system for the Brazilian economy, constructed for 2 regions (Northeast and Rest of Brazil), for the years of 1985, 1992, and 1995

However, the use of economic landscapes does not replace previous methods of analysis used with input-output systems; it only uncovers a new and better way of showing information contained in an input-output table that otherwise would be difficult to analyze and to show to a broader audience of non input-output specialists. 
The use of economic landscapes is still in the beginning, and new ways of using it are still to be discovered. However, a further development is illustrated here, and alternative perspectives will likely be discovered.

\section{References}

Agrianual. Various Issues. São Paulo: FNP.

Associação das Indústrias de Açúcar e Álcool do Estado de São Paulo. Boletim Informativo. Various Issues.

Baer W. (1996). A Economia Brasileira. São Paulo: Nobel.

Bonelli, R., and R.R. Gonçalves (1998). "Para Onde Vai a Estrutura Industrial Brasileira?” In IPEA (1998). A Economia Brasileira em Perspectiva - 1998. Rio de Janeiro: IPEA. Vol. 2, Chapter 16, pp. 617-664.

Conjuntura Econômica (1997). "Indicadores Econômicos," 51, no. 8.

Considera, C.M. and M.H. Medina (1998). "PIB por Unidade da Federação: Valores Correntes e Constantes - 1985/96”. Rio de Janeiro: IPEA, Texto para Discussão, 610. 32p

Hewings, G.J.D M. Sonis, J. Guo, P. R. Israilevich and G. R. Schindler, (1998) "The hollowing out process in the Chicago economy, 1975-2015," Geographical Analysis, 30, 217-233

IBGE (1997a). Anuário Estatístico do Brasil 1996, v. 56. Rio de Janeiro.

IBGE (1997b). Contagem da População 1996. Rio de Janeiro.

Marjotta-Maistro, M. C. (1998). Análise do Consumo Industrial de Açúcar no Estado de São Paulo. Master Dissertation. Departamento de Economia, Administração e Sociologia. ESALQ. University of São Paulo. 100 p. 1998

Melo, H.P., F. Rocha, G Ferraz, G. di Sabbato, R. Dweck (1998) “O Setor Serviços no Brasil: uma Visão Global - 1985/95." In IPEA (1998). A Economia Brasileira em Perspectiva. Rio de Janeiro:IPEA. Vol. 2, Chapter 17, pp. 665-712.

Moraes, M.F.D. (2000). A Desregulamentação do Setor Sucroalcooleiro do Brasil.

Sonis, M., G.J.D. Hewings, and J. Guo (2000). "A New Image of Classical Key Sectors Analysis: Minimum Information Decomposition of the Leontief Inverse". Economic Systems Research. 12 (3). pp. 401-423.

União da Agroindústria Canavieira do Estado de São Paulo. Boletim Informativo. Various Issues. USDA. Information from the site www.fas.usda.gov. 